\title{
A Análise do Discurso Como Estratégia de Pesquisa no CAmpo DA AdMINISTRAÇ̃̃o: UMA Visão G LOBAL
}

\author{
Prof. Augusto Cézar de Aquino Cabral \\ Doutor em Administração - Professor Adjunto \\ Instituição: UFC - FaculdadedeEconomia, Administração, \\ Atuária,Contabilidadee Secretariado Executivo \\ cabal@ufc.b
}

\section{RESUMO}

Este ensaio constitui uma reflexão sobre a Análise do Discurso (AD), quevem ocupando um espaço cada vez mais significativo nos estudos organizacionais em geral e na administração em particular. Elenão visa aprofundar conhecimentos que se inserem no campo da lingüística. Entretanto, elabora uma síntese de algumas das fundamentações teóricas daAD . Com o intuito de clarificar o campo de atuação da $\mathrm{AD}$, ele inicia-se com aapresentação de suas correntes principais, uma divisão metodológica que delimita orientações distintas tanto no campo teórico quanto no prático. Em seguida, toma-se como ponto de partidano embasamento teórico as contribuições de Saussure. Posteriormente, as teorias de atos de fala, ou pragmáticas, assim como as teorias de enunciação e o conceito de destinaridade são brevemente explorados, como forma de fixar um referencial que guie o leitor e o permita compreender a premência de se submeter o discurso da administração às indiscretas lentes da AD . D espertara consciência para esta possibilidade, enfatizando o seu potencial, eressaltar aspectos-chave que sobressaem-sena análise do discurso da administração é o intuito maior. D ados os objetivos de desmascarar os implícitos, os silêncios e pluralizar as compreensões, 0 enfoque qualitativo da AD éapontado como o mais apropriado. A refelexão apresentada demonstra que, enquanto 'ciência', a administração se faz através de discursos, com significados explícitos e latentes marcados por ideologiase, conseqüentemente, através de posições comprometidas.

PALAVRAS-CHAVE: Análise do discurso, Estudos O rganizacionais e Estratégia de Pesquisa.

\section{ABSTRACT}

Thispaper developsa reflection on DiscourseAnalysis (DA), which hashad an increasingly meaningful rolein the field of organizational studies, especially in administration. It doesnot intend to deepen knowledgein thefield of linguistics. However, it developsa synthesis of someof theD A theoretical foundations. With thepurposeto clarify thework field, it beginswith thepresentation of the DA main streams, a methodological division which delimitsdistinct orientationsboth in thetheoretical and practical fields. Then, it takes Saussure'scontributionsas thestarting point of thetheoretical foundation. After that, thetheories of speech acts, or pragmatics, aswell as the theories of enunciation and theconcept of destinity are briefly explored, asa way to establish a background to guide thereader and allow him/ her to understand theurgeto submit thediscourse of administration to theindiscreet DA lenses. To raiseconsciousnessabout thispossibility, emphasizing itspotential, and to point out key aspectsthat emerge in thediscourseanalysis of theadministration isthe main goal. Given thegoalsto unmask theimplicit, the silencesand to pluralizetheunderstandings, thequalitative approach of theDA isdeemed themost appropriate. The reflection presented showsthat, asa science, administration ismade up of discourses, with explicit and latent meanings marked by ideologiesand, therefore, with compromised positions.

KEY WORDS: Discourseanalysis, organizational studies, and research strategy. 
"One of my diseases, one of my thingsin life, isthat anything that is secret, I try to undo"

(Feynman 1976).

\section{INTRO DUÇÃO}

Nautilização daAnálise do Discurso (AD) como estratégia de pesquisa no campo da administração, múltiplas são as abordagens possíveis. As características do material trabalhado e os objetivos pretendidos são os elementos norteadores. Ao perseguiro desafio de construirinterpretações, aAD parte do pressuposto de que "um sentido oculto deve ser captado, 0 qual, sem uma técnica apropriada, permanece inacessível" (MAINGUENEAU, 1997, p.11). A busca da significação oculta não implica a crença em um único sentido, em uma única verdade. 0 foco de interesse éa construção de procedimentos capazes de transportar o olhar-leitor à compreensões menos óbvias, mais profundas através da desconstrução do literal, do imediato. Assim,

desvendando os mistérios da linguagem, rompendo a opacidade das palavras e das frases, desvelando os segredos dos subentendidos, penetrando nos implícitos do dito, essa análise vem compondo um instrumental metodológico que, a partir do conceito de discurso com base em teorias lingǘsticas, permite compreender-lhe os sentidos múltiplos criados através da complexa trama de atores que 0 realizam. (BALLALAI, 1989, p. 56)

Enquanto estratégia de pesquisa, aAD éde difícil caracterização. Sua aparente volatilidade advém do fato de que seu objeto, "ora perspectiva-se lingüisticamente, ora ideologicamente, caracterizando, talvez, uma pretensa antinomia que, se por um lado, favorece um maior aprofundamento em cada uma dessas abordagens, por outro, impede a visão da totalidade" (Pereira 1991: 7). A AD éatualmente interdisciplinar. As práticas da linguagem continuam sendo a sua base, mas não o seu único fundamento. Ela contribui para vários campos do conhecimento que reconhecem a linguagem como parte integrante do discurso. Um dos problemas advindo do seu caráter eclético éa dificuldade de se efetuar compatibilizações metodológicas entre as diversas disciplinas que ao mesmo tempo lhe servem de subsídio e nela buscam subsídios. A diversidade de abordagens gera interfaces de interesses intercambiáveis. Como evidencia este trabalho, vários autores têm contribuído para a evolução daAD .

Este ensaio constitui uma reflexão sobre $\mathrm{AD}$, que vem ocupando um lugar cada vez mais significativo nos estudos organizacionais em geral e na administração em particular. Embora não busque aprofundar conhecimentos que se inserem no campo da linguística, este trabalho elabora uma síntese de algumas das fundamentações teóricas da AD. Com 0 intuito de clarificar o campo de atuação da AD , este ensaio inicia-se com a segmentação esquemática das duas grandes correntes que integram esta disciplina. Esta divisão metodológica delimita orientações distintas tanto no campo teórico quanto no campo prático. Em seguida, toma-se como ponto de partidana fundamentação teórica da AD as superadas, porém clássicas contribuições de Saussure. Posteriormente, as teorias de atos de fala, também designadas de pragmáticas, assim como as teorias de enunciação e 0 conceito de destinaridade são brevemente explorados como forma de fixar um referencial que guie o leitor e melhor o permita compreender a premência de se submeter o discurso da administração às indiscretas lentes da AD .D espertar a consciência desta possibilidade e chamar a atenção do seu potencial e para alguns aspectos chaves que sobressaem-se na análise do discurso da administração enquanto problemática de pesquisaé o intuito maior deste ensaio. D ados os objetivos propostos de desmascarar os implícitos, os silêncios e pluralizar as compreensões, o enfoque qualitativo da AD éapontado como 0 tipo de análise mais apropriado.

\section{AS DUAS GRANDES LINHAS DA AD}

Para efeitos didáticos, a AD pode ser dividida em duas amplas linhas que, embora apresentem diferenças metodológicas e teóricas, surgem, ambas, da necessidade imposta pela lingüística de definir uma nova unidade de análise que ultrapassasse os limites da frase: 0 texto. Na linha anglosaxã, ao contrário do que ocorrena corrente européia, a AD não é afetada pela dicotomia saussuriana língua e fala e constitui, assim, uma mera extrapolação da gramática. Por ter um enfoque intralingüístico, essa corrente da AD privilegia as interseções entre os níveis sintático e semântico. Suas investigações tendem a enfocar de modo descritivo a questão da coesão e coerência textual (PEREIRA, 1991, p. 8-9). Nestaperspectiva, aAD apoiasenos enfoquesinteracionistas e etnometodológicose tem como objeto central de estudo a conversação ordinária (MAINGUENEAU, 1997, p. 15).

A linha européia daAD segue a tradição, mais especificamente francesa, de atrelar uma perspectiva histórica ao estudo reflexivo dos textos (MAINGUENEAU, 1997, p. 9). Neste sentido, a AD não evidencia-se originalmente como uma disciplina de saber, mas como fruto de uma prática escolar, voltada para a "explicação de textos," exercida na conjuntura intelectual dos anos sessenta, a articulação, sob o paradigma estruturalista, da lingüística, do marxismo, e da psicanálise em torno da "escritura". D esta forma, aAD européia ao englobar em sua evolução questões filosóficas, políticas e ideológicas, constitui domínio não apenas de lingüistas, mas também de psicólogos e historiadores (PÊCHEUX 1984 citado em MAINGUENEAU, 1997, p. 10). $O$ objetivo da $A D$ francesa é explicitar a relação entre linguagem e ideologia (PEREIRA, 1991, p. 11). 0 quadro abaixo sumaria algumas dessas diferenças. 


\begin{tabular}{|l|l|l|}
\hline & AD francesa & AD anglo-saxã \\
\hline Tipo de Discurso & $\begin{array}{l}\text { Escrito- } \\
\text { (quadro institucional doutrinário) }\end{array}$ & $\begin{array}{l}\text { Oral - } \\
\text { conversação cotidiana comum }\end{array}$ \\
\hline $\begin{array}{l}\text { Objetivos } \\
\text { Determinados }\end{array}$ & $\begin{array}{l}\text { Propósitos Tcxtuais } \\
\text { explicação - forma } \\
\text { (construção do objeto) }\end{array}$ & $\begin{array}{l}\text { Propósitos Comunicacionais } \\
\text { descrição - uso } \\
\text { (imanência do objeto) }\end{array}$ \\
\hline Método & $\begin{array}{l}\text { Estruturalismo } \\
\text { (lingüística c história) }\end{array}$ & $\begin{array}{l}\text { Interacionismo } \\
\text { (psicologia c sociologia) }\end{array}$ \\
\hline Origem & Lingǘstica & Antropologia \\
\hline
\end{tabular}

Q uadro1: A Linha Anglo-saxã e a Linha Européia da AD

Fonte: Gadet F. L'anlyse de discourse et l' “Interprétation” in Maingueneau (1997: 16). dois primeiros pares mostraram-se de extrema relevância nos estudos lingüísticos posteriores. A dicotomia língua/ fala relaciona-se à oposição social/ individual e encontra o seu respaldo na sociologia, então incipiente, masjálegítima (CARVALHO, 1984, p. 61-62). A dicotomia sincronia/ diacronia relacionase ao uso da língua em seu momento atual em oposição a seu uso em termos das fases de sua evolução histórica. Tendo estabelecido a língua como um sistema autônomo, a obra de Saussure pode ser vista como uma "bomba epistemológica" de efeito retardado, montada desde 1916 mas detonada apenas nos meados da década de 1960 com o advento do estruturalismo e a inserção do enfoque descritivo em substituição ao enfoque normativo tradicionalmente utilizado pela lingüística.

\section{A AD E SUA EVOLUÇÃO : ALG UMAS PERSPEC TIVAS TEÓ RICAS} linguagem. Como extensão de sua personalidade perfeccionista, Saussure empenhou-se em delimitar metodologicamente o campo dos estudos lingǘsticos, tarefa, segundo ele, necessariamente anterior ao trabalho científico de desenvolvimento de teorias de alcance universal. Superar o descenso, a imprecisão e a subjetividade da terminologia lingüística foi o seu ponto de partida. Esta preparação preliminar visava estabelecer uma linguagem unívoca, um padrão lingüístico, uma metalinguagem indispensável à elaboração racional do estudo lingüístico (CARVALHO , 1984, p. 25-27). A lingüística, afirmou Saussure em seu CLG ${ }^{1}$, "jamais se preocupou em determinar a natureza do seu objeto de estudo. O ra, sem essa operação elementar, uma ciência é incapaz de estabelecer um método para si própria" (SAUSSURE, 1987, p. 10).

A Teoria do Signo Lingüístico, na qual os dois elementos interdependentes e inseparáveis significante(imagem acústica) e significado (sentido ou conceito) constituem o signo e a D icotomia Langue/ Parole (língua e fala) constituem as contribuições mais marcantes de Saussure, para quem a língua é um sistema de signos constituídos pela "união do sentido e da imagem acústica." Sua doutrina centra-se em visões dicotomizadas, em dualidades, como ele mesmo ressaltou: “... o fenômeno lingüístico apresenta perpetuamente duas faces que se correspondem e das quais uma não vale senão pela outra" (Saussure 1987: 15). D entre suas noções bipolares, língua/ fala, sincronia/ diacronia, sistema/ não-sistema, relações sintagmáticas/ paradigmáticas, os
A análise do discurso pode demonstrar que aquilo que é lido não é a realidade, mas apenas um relato da realidade propositadamente construído de um determinado modo, por um determinado sujeito. Através do destrinchamento do funcionamento dos textos e da conseqüente observação de sua articulação com as formações ideológicas, ela permite desvendar, no contexto da sociedade, o confronto de forças, as relações de poder, os domínios do saber. A AD considera essencial a relação da linguagem com a exterioridade, que pode ser compreendida como as condições de produção do discurso. Nessas condições estão incluídos não apenas o falante e o ouvinte, mas também o contexto histórico-social eideológico da comunicação. Embora parta de conceitos estritamente técnicos advindos da lingüística, a $\mathrm{AD}$ enquanto técnica de pesquisa não é uma abordagem hermética, de domínio exclusivo dos lingüistas. Ela englo ba e pressupõe uma variedade de conhecimentos de áreas afins como a psicologia, a sociologia, ea filosofia. Portanto, mostra-se eminentemente eclética e aberta à abordagens diversas.

\section{O CO NCEITO DE DISCURSO E DE FO RMAÇÃO D ISCURSIVA}

0 conceito de discurso advém originalmente da dicotomia saussuriana língua/ fala. Se por um lado a língua

1 CLG - Cours de Linguistique G énérale: compilação dos três cursos de Lingüística G eral ministrado por Saussure entre 1906-1911 na Universidade de $\mathrm{G}$ enebra. Trata-se de obra póstuma e incabada desenvolvida a partir de anotações de aula com a contribuição de seus discípulos Charles Bally, Albert Sechehaye e Albert Riedlinger. 
constitui um sistema independente do indivíduo e tem caráter coletivo, por outro lado, afala diferencia-se por ser a transformação e a atualização deste conjunto de regras sistematizadas para a esfera individual. As combinações seletivas que o sujeito falantefaz ao utilizar o código da língua para comunicar-se constituem a fala(SAUSSURE, 1987, p. 86-87). Essa fala seria o próprio discurso. 0 primeiro conceito de discurso vem desse processo combinatório que caracteriza a fala (BALLALAI, 1989, p. 61). Segundo D audi (1986, p. 268), "0 conceito de disaurso denota um conjunto de enunciados, conceitos, teses e teorias faladas e escritas, que juntas formam uma concepção articulada de alguma coisa em particular."

Recentemente, o termo discurso tem sido utilizado com ampla liberdade em uma variedade de contextos. Suas variadas acepções têm contribuído para dificultar a delimitação do objeto de estudo da AD. Visando contornar este dilema, a AD tem tomado emprestado de Foucault (1969) o conceito de formação discursiva: "um conjunto de regras anônimas, históricas, sempre determinadas no tempo e no espaço que definiram em uma época dada e para uma área social, econômica, geográfica ou lingǘstica dada, as condições de exercício dafunção enunciativa” (FOUCAULT, 1969, p. 153). Pelaótica da formação, aAD consiste em "associar, de forma mais ou menos direta, um conjunto de textos a uma região definida da sociedade, pensada em termos de classes ou subclasses sociais (MAING UENEAU, 1997, p. 54). D este modo, uma formação discursiva é uma "zona onde se manifestam com alguma perturbação as aspirações da classe que seria seu suporte" (MAING UENEAU, 1997, p. 54).

Explicando o conceito de formação discursiva, D audi (1986, p. 141-145) afirma que, aos termos teoria, disciplinae ciência, tidos como historicamente carregados, Foucault prefere a expressão formação discursiva que sugere que uma teoria ou ciêncianunca está plenamente desenvolvida. Ao formar uma unidade, um conjunto de enunciados (énonce) podeser moldado em uma teoria científica, que constitui um discurso sobre alguma coisa. D esta forma, a formação discursiva é 0 processo de desenvolvimento e construção que, a partir de enunciados dispersos, formaum discurso. D audi mostra que um conjunto de condições e circunstâncias, as regras de formação, torna possível eregulamentaaformação discursiva: as superfíciesdeemergência, que indicam as esferas social, política, econômica e cultural em que aformação discursiva aparece; as autoridadesde delimitação, representadas por especialistas ou instituições formalmente reconhecidos como competentes e legítimos para expressar opiniões; e as matrizesde significação, o sistema de classificação utilizado para correlacionar ou diferenciar vários objetos entresi.

\section{AS TEO RIAS DE ENUNCIAC̃̃O E AS TEO RIAS PRA G MÁTICAS}

O s modos como a língua através da fala é atualizada deram origem às Teorias da Enunciação e as Teorias Pragmáticas que constituem, de um certo modo, uma continuidadee não uma ruptura com Saussure. É através da enunciação que o sujeito se apropria da língua e então se posiciona. E são as pragmáticas que preocupam-se com as condições de produção, de enunciação. A análise do discurso consolida-se então como um novo espaço de reflexão sobre a linguagem. Constitui-se de hipóteses, princípios e procedimentos que, de um certo modo, estabelecem um confronto com uma dada tradição de trabalhar o campo da lingüística. Ao mesmo tempo, a $\mathrm{AD}$ apresenta-se como uma continuidade e alimenta-se de contribuições de diversas áreas do conhecimento, tais como a filosofia e a sociologia. Embora tenha incorporado o trabalho dos lingüistas neste processo de continuidade, a AD propõe agora um modelo de análise lingüística no qual os fatos são necessariamente relacionados com o uso da linguagem em situações históricas determinadas e por sujeitos concretos. Neste contexto, há desenvolvimentos diversos com metodologias diferenciadas. A AD não é, pois, uma abordagem única. Assim como o seu objeto, o discurso, ela é plural e varia conforme diferentes pontos de vista. Ademais, o produto dos esforços de pesquisa de AD servem de subsídio para umavariedade de ciências, dentre elas aadministração, a antropologia, ea sociologia.

É a partir do trabalho de Benveniste (1966) que a visão estruturalista ${ }^{2}$, com a qual uma ampla variedade de autores está ou esteve associada, começa a ser ultrapassada. Superando o sistema e enfocando o sujeito, Benveniste lança os fundamentos da lingüística da enunciação. As teorias da enunciação constituem uma interface da linguagem com a psicanálise. Nesta perspectiva, é na e pela linguagem que 0 homem se constitui como sujeito. Ou seja, a subjetividade, não contemplada pelo estruturalismo e compreendida como a capacidade do locutor de se constituir como sujeito, é introduzida. Ao invés de ser encarada como um instrumento, a linguagem é encarada como tendo uma função instrumental. A categoria de pessoa, comum à todas as línguas, definea subjetividade e os eixos de espaço e de tempo. A través do contraste e da reciprocidade entre o " $\mathrm{eu}$ " e o "tu" em um processo de polaridade sem simetria ocorre a formação da identidade do sujeito. Neste cenário, os pronomes pessoais recebem atenção especial. Eles não se referem aconceitos ou indivíduos e escapam aos estatutos dos outros signos lingüísticos. A língua é assumida por aquele que diz "eu." 0

2 Há na realidade uma variedade de "estruturalismos," abordagens com diferentes nuanças e com as quais autores diversos como Piaget, Lévi-Strauss, Althusser, Chomsky, Foucault, Leach, e Bourdieu, dentre outros, têm sido associados. 
"eu" só é identificável em uma instância de discurso. Não remete à uma realidade de mundo, mas de discurso. O s conceitos da gramática normativa, tradicional não se enquadram nesta visão. Neste contexto, a terceira pessoa eqüivale à não pessoa. Ademais, não existe plural de pessoa, mas apenas dilatação, associação, ou ampliação. D esta forma, "nós" não é a multiplicação do "eu," que é único. A expressão da pessoa afeta os domínios de tempo e espaço, tidos como autônomos. 0 tempo e o espaço são, então, ordenados em função da enunciação do aqui-agora. No discurso, o ato de enunciação éque ordena em termos de tempo e espaço. Três modos enunciativos podem ser encontrados no discurso: 0 elocutivo, em que o "eu" se revela; 0 alocutivo, em que há marcas do "tu"; e o delocutivo, que é neutro e não trai sua presença por marcas.

Estendendo a noção saussuriana de língua e fala, Hjelmslev (1966) amplia o conceito de discurso refinando a idéia de uso, compreendido como um conjunto de hábitos de uma dadaso ciedade, eincorporando-lheaidéia do social. Nesta nova perspectiva, o discurso está além da mera visão social. É resultante do confronto entre 0 individual e o contextual. 0 discurso passa a ser um ato resultante de uma situação de comunicação, um produto de uma relação em que o emissor e 0 receptoratuam conjuntamente. Estapercepção marcaagrande contribuição dapragmática (BALLALAI, 1989, p. 62).

Segundo Bourdieu (1983: 53), tanto os fatores lingüísticos quanto os extralingüísticos são necessários à compreensão daquilo que é dito. As condições de produção do discurso, a situação, mais do que o próprio sujeito falante, são determinantes do sentido produzido. 0 contexto revela os implícitos. Para a AD, a enunciação implica uma referência de um estado de coisa da qual se está falando e transporta o receptor além dos limites lingüísticos dos elementos da fala de forma que o seu decodificador deve considerar não apenas aquilo que é enunciado, mas também 0 contexto da enunciação (BALLALAI, 1989, p. 71). "Estudar a frase e o discurso a partir do seu caráter utilitário, ou seja, revelar o sentido pragmático dessa frase ou desse discurso, em função de sua utilização, pelo locutor, em um determinado contexto" (BALLALAI, 1989, p. 71) é a contribuição da pragmática para $\mathrm{ADD}$.

Somente com as teorias dos atos de fala, as pragmáticas, foi queaAD inscreveu aatividade da linguagem em espaços institucionais, abandonando sua antiga tradição de tomar como objeto os corpus apreendidos independentemente de seus atos de enunciação e de suas circunstâncias (MAING UENEAU, 1997, p. 29). A enunciação, como ato, deu origem às pragmáticas. Ela confunde-se com 0 ato. 0 discurso é a língua assumida pelo homem que fala na condição de subjetividade. Surge, então, a noção de performatividade. Dizer éfazer. Um performativo é um tipo especial de enunciação. 0 uso de verbos performativos, ver- bosquerealizam, esclarece estaperspectiva. 0 emprego detais verbos na primeira pessoa implica a realização de um ato desde que existam certas condições sociais. Este tipo de ato realiza-sepelaprópriaenunciação. Por exemplo, a enunciação "abro a seção" éem si um ato, desde que o sujeito enunciador esteja em posição legítima. D a mesma forma, "eu juro" é um ato, enquanto "elejura" é a descrição de um ato. "Na perspectiva pragmática, a linguagem é considerada como uma forma de ação; cada ato de fala (batizar, permitir, mas também prometer, afirmar, interrogar, etc. é inseparável de uma instituição, aquela que este ato pressupõe pelo simples fato de ser realizado" (MAINGUENEAU, 1997, p. 29). A partir das considerações da pragmática, as circunstâncias e os elementos extralingǘsticos começam a ser consideradas na AD. Este enfoque abriu caminho para perspectivas mais amplas.

\section{A DESTINARIDADE E A TEO RIA DA ARG UMENTAÇÃO}

Mais do que passar informação, o objetivo do discurso é obter a adesão através da utilização da linguagem como forma de persuadir, seja de forma conspícua ou não. Trabalhando 0 não dito, o latente, 0 implícito, o discurso argumentativo faz-se sedutor. Assim como a pragmática leva em consideração o outro e o contexto (seu e do outro), a argumentação estabelece o discurso com o outro no intuito de mudar esse outro. D esta forma, além de ser um processo de comunicação, o discurso, reconhecendo a relevância crítica da destinaridade, se organiza como um processo intencional de ação sobre o outro (BALLALAI, 1989, p. 72). A proposta argumentativa é um corolário da destinaridade do discurso. A argumentação é montada em função de um dado público alvo, de um auditório particular. D ado que todo discurso visa convencer aquele a quem se destina, a dimensão argumentativa é essencial à linguagem. " 0 orador (locutor/ emissor) fica obrigado, se ele quiser agir sobre 0 outro, a se adaptar ao seu auditório, seja ele presente, seja ele ausente, como no caso do texto escrito. Na verdade, mudando de auditório, o discurso muda" (BALLALAI, 1989, p. 72).

Todo discurso é fonte de diálogo, explica Ballalai (1989, p. 63-65). Como as teorias lingǘsticas evidenciaram ao longo de seu processo de evolução, a responsabilidade pela produção do sentido do discurso não é apenas do sujeito falante, mas de todos os elementos componentes do discurso.É em função da comunicação que o discurso existe. Ballalai ressalta, entretanto, que a organização da comunicação não se faz tão linearmente como dão a entender Saussure e outros lingüistas. A relação binária emissor-receptor nem sempre capta toda a complexidade da comunicação uma vez que o ato da fala pode envolver mais de dois actantes ou personagens. 0 alocutor, aquele a quem o discurso é dirigido, e o ouvinte não são necessariamente amesmapessoa. A relação de comunicação pressupõea intencionalidade, explícita ou tácita, por parte 
do emissor de dirigir o seu discurso a um destinatário específico, que por sua vez pode reconhecer-se como tal ou não. $\mathrm{Da}$ complexidade desta trama possível entre os componentes da comunicação o discurso adquire sua pluralidade potencial. Para o autor, ao romper o seu invólucro dual, receptor-emissor, 0 discurso torna-se múltiplo ea detecção de seu sentido passaa requerer a atenção de todos os seus actantes: 0 autor da fala (locutor), os agentes dos atos ilocucionários (enunciadores), o ser a quem as palavras são ditas (alocutor) e aqueles que são pacientes dos atos (destinatários).

Este emaranhado em que consiste a real organização da comunicação constrói uma teia de sentidos na qual uma pluralidade de vozes fazem-se presentes. Na construção do sentido de um texto ou de uma comunicação também ocupa papel de destaque o conjunto de saberes, crenças e valores, previamente compartilhados pelos personagens engajados no discurso. É também em função desses saberes que o discurso encontra um dado tipo de ressonância e tem seu sentido produzido. D ado que o discurso é construído a partir tanto do saber do emissor quanto do receptor, a questão de sua destinaridade torna-se bastante relevante. 0 discurso edifica a imagem do destinatário do ponto de vista descritivo e narrativo. D esta análise dos elementos do discurso conclui-se que o sentido das palavras de um discurso varia conforme as posições que ocupam aqueles que as empregam. Ademais, o sentido depende do contexto, que, por sua vez, inclui um saber anterior. Logo, o sentido é um lugar dialético, plural (MEYER, 1982, p. 134); portanto, indeterminado e vulnerável à subjetividades. E mbora "vago e impreciso", ele é repleto de "implícitos e subjacências" (BALLALAI, 1989, p. 66-67).

Emborapossa serrelativamente circunscrito em simesmo, o discurso não pode ser fechado. Sendo fonte de diálogo, ele tem que se articular com outros discursos. Como Linstead (1994, p. 64) explica, se é certo que uma noção básica no conceito de discurso é a de que ele possa ser reproduzido, também écentral a noção de que ele possa ser resistido, estando, portanto, sujeito à mudanças, ànegociações. Há, entretanto, à medida em que uma determinada formação ideológica ganha maior hegemonia em um dado momento, a tendência do discurso solidificar-se, alçando um grupo, ou sustentando sua superioridade, à uma posição de destaque, de dominação. Ademais, enfatiza o autor, embora a ascendência de um discurso implique uma certa uniformidade econômica, política, intelectual e moral, o que, por sua vez significa uma solidificação, nenhum discurso, por mais poderoso ou sólido que pareça, estáisento dapossibilidade de desconstrução. Precisando sempre ser reproduzido, sustentado, negociado, o discurso nuncaé permanentementenormalizado. Diante desta realidade, a pesquisa nesta área deve concentrar-se, segundo Linstead, nas condições que tornam mais prováveis a reprodução do discurso e nas respostas dos atores sociais em situações reais dentro de uma dada organização.

\section{O DISCURSO DA ADMINISTRAÇ̃̃O}

Assim como em várias outras áreas, também na arena da administração, a orientação funcionalista e quantitativa de pesquisa impõe sua supremacia por colocar-se como o enfoque racional de pesquisa, o verdadeiro enfoque científico. Sua pretensa exclusividade científica éa base de sua legitimidade e determina a exclusão de abordagens não quantitativas, portanto, não-científicas, ineficientes e não-racionais. A orientação qualitativa érepudiada pelos proponentes da abordagem quantitativa, dentre outras razões, pelo fato de não prontamente possibilitar a replicação dos resultados, por prestar-se apenas ao desenvolvimento de uma compreensão inicial e não a recomendação de ação, por não partir de coletas estruturadas, de amostras representativas, e de análises estatísticas. Entretanto, a abordagem qualitativa tem o grande mérito de trabalhar os aspectos subjacentes da organização, dentre eles os discursos e os 'não-discursos'. É especialmente alinhada a este mérito que $\mathrm{AD}$ impõe-se.

Embora seja possível utilizar uma abordagem quantitativa na AD e com isso conferir maior legitimação científica ao estudo, aabordagem qualitativa ancorada na tradição francesa éo enfoque aqui defendido. A objeção ao enfoque quantitativo da AD advém do fato de que o mesmo implica um certo automatismo e rigidez no tratamento do "material linguageiro" estudado uma vez que nesta perspectiva a análise baseia-se no levantamento estatístico da freqüência de aparecimento de certos elementos do discurso. A abordagem qualitativa, por outro lado, apoia-se em inferências que são sempre fundamentadas em indícios; logo, há mais espaço para a maleabilidade, para as injuções, e para a intuição (BALLALAI, 1989, p. 76-77).

D ada a complexidade e a pluralidade do discurso da administração, cuja expressão e inspiração maior talvez seja o conjunto de teorias organizacionais que evoluíram ao longo do século, a sua análise demandaa utilização de uma estratégia de pesquisa metodologicamente sofisticada, capaz tanto de interpretar as mensagens explícitas quanto de desvendar os sentidos ocultos, os silêncios, as omissões. "Ainda que propugne uma neutralidade científica, o discurso produzido pelas teorias, pelas propostas de ação, pelas justificativas de esquemas organizacionais esconde intenções não confessadas ou não confessáveis, trazendo em nível do explícito declarações que se opõem às subjacentes e que, se denunciadas pela revelação do implícito, apresentam intenções contrárias às declaradas" (BALLALAI, 1989, p. 57).

D eve-se considerar, entretanto, que a teoria organizacional, fontee expressão significativas do discurso da administração, tem sido considerara como sendo desincorporada, sem raízes (e.g. HOFSTED E, 1980) no sentido de que negligencia ou mesmo ignora, conscientemente ou não, não apenas a natureza filosófica dos problemas por ela levantada, mas também a ideologia intrínseca aos pesqui- 
sadores que a geram. Em parte, esta questão advém do que pode ser chamado de paradoxo do conhecimento (DAUDI, 1986, p. 13): o fato de que a ideologia geral na qual o pesquisador está inserido dita, direta e indiretamente, o conteúdo do seu discurso. Porém, mais relevante do que despertar a consciência do viés ideológico napercepção do mundo, é enfatizar a possibilidade de desmistificação do discurso uma vez que 0 mesmo, como demonstra Foucault (1996), não assenta-se em verdades absolutas e universais, mas sim em uma base frágil e arbitrária. N este contexto, D audi (1986, p. 13) alerta que mais do que o questionamento da natureza verdadeira ou não do discurso, o cerne da questão é sua legitimação que refere-seaos mecanismos que regem suaformação. Tomando 0 discurso do poder como exemplo, 0 autor mostra que 0 discurso do poder não é sobre o poder; ao invés disso, ele produz poder. Em outras palavras, o discurso produz o seu objeto, o multiplica e, assim, torna-se mais forte, mais normatizador. D esta forma, 'to speak of the dymystification of the discourseon power is to become aware of, and to draw attention to, the power of disoourse, i.e. that power which holds us prisoner of own discourses' (D AUDI, 1986, p. 13-14).

A AD demonstraque, enquanto 'ciência', a administração "se faz através de discursos sucessivos marcados por várias ideologias e, conseqüentemente, através de posições nitidamente comprometidas. 0 discurso da administração se faz, como qualquer outro discurso científico daárea humana, com significados explícitos ou latentes. A análise desses significados poderá trazer uma importante contribuição para melhor precisar os conceitos de administração, sobretudo porque esse discurso não éum discurso acabado, fechado, concluído. Ele estará permanentemente se construindo, fazendo-se nas suas coerências e nas suas contradições." (BALLALAI, 1989, p. 61). Ademais, como salientam Alvenson e D eetz (1996, p. 207), diferentes discursos podem coexistir, embora com mais ou menos poder, ou seja, ocupando uma posição central ou marginal.

A complexidade do ato de palavra, anteriormente discutida, evidencia a necessidade de se submeter o discurso da administração à AD como forma de se explorar a vasta rede de elementos que, explícita ou implicitamente, o compõe e lhe concede sentido. "Não só vai interessar a essa análise conhecer o sujeito falante, quer dizer o emissor do discurso, o locutor, como também o receptor, direto e imediato, ou indireto, onde 0 emissor assentou a destinaridade de seu discurso. Importará saber, inclusive, o mundo subjacente a esse discurso, a complicada história dos saberes e os reconhecimentos desses saberes (e crenças) por parte tanto do emissor quanto do receptor, até chegar a detectar as intenções do discurso" (BALLALAI, 1989, p. 67).

Um outro ponto a ser considerado é o fato de que os estudos organizacionais e sua teorização têm sido descritos como constituindo um território historicamente contestado (REED , 1996). Esta contestação histórica advém naturalmente não apenas de diferenças nas orientações intelectuais dos inúmeros autores que colaboram com este campo de conhecimento, mas também de diferenças políticas eideológicas nas orientações destes autores. No lugar de complementaridade e superação, manifestam-se lutas e paradigmas incomensuráveis. Por sua pluralidade, complexidade, e dinamicidade 0 território caracteriza-se como um verdadeiro laboratório para $\mathrm{a} A \mathrm{D}$, que com suas ferramentas pode fornecer os meios de auscultá-lo, interpretá-lo e compreendê-lo. Como resultado deste esforço, umanova visão do mundo organizacional pode emergir, lançando luzes sobreáreas nebulosas, como as realidades das relações de trabalho, desmistificando conceitos, como o da racionalidadee o da eficiência, queperpassam grandeparte dos estudos organizacionais.

Em diferentes enfoques ou tópicos organizacionais prevalecem sempre algumas poucas vozes, muitas vezesoponentes, que tendem a dominar o cenário em questão. Tomando o estudo do poder como exemplo, Hardy e Clegg (1996) explicam como duas correntes divergentes dominam as análises que fundamentam as pesquisas deste tema. A tradição mais antiga alimenta-se dos trabalhos de Marx e Weber. Entendendo o poder como dominação, esta corrente tem como foco o conflito deinteresses ebusca compreender de que modo o poder entranha-se nas estruturas organizacionais de modo a servir a alguns, mas não a todos os grupos. Nesta perspectiva, as ações que confrontam o poder constituem resistência. A tradição mais moderna, a linha gerencial de mainstream, toma como um dado aforma como o poder é distribuído na estrutura organizacional formal, que é vista não como estrutura de dominação mas como estrutura de autoridade formal, legítima e funcional. A maneira como os grupos adquirem e usam poder que não lhes foi formalmente concedido é 0 seu foco. Em resumo, ao tratar do poder, as vozes fundadoras referem-se a diferentes fenômenos, adotam diferentes valores; conseqüentemente, constroem diferentes discursos. Mesmo os estudos delas advindos tendem a meramente estender suas concepções básicas. A aplicação da AD aos estudos do poder ajudaria na compreensão, na elucidação dos porquês subjacentes a este padrão de desenvolvimento. Por que cada uma dessas vozes elege e reconhece como legítimos apenas um tipo de discurso, uma dada audiência. A quem cada uma delas fala? E o que lhes diz? O desmascaramento dos implícitos talvez facilitasse a construção de uma ponte que abriria a possibilidade de novos e mais completos saberes.

A AD tem sido utilizada também na decomposição do conceito de estratégia. Partindo do reconhecimento da centralidade da noção de estratégia para os estudos organizacionais, Whipp (1996) alerta para necessidade de se dissecar as camadas de significado quea palavrae os seususos têm portado. Tal esforço torna-se mais pungente pelo fato de que o uso do termo 'estratégia' e de seu adjetivo 'estratégico' tem se estendido muito além do circuito da administração, passando a fazer parte da fala popular. A palavra estratégiaé 
genericamente utilizada de forma direta e com conotações positivas para exprimir a relevância do projeto em questão ea grandiosidade dos objetivos, e para sugerir um senso de raciocínio e planejamento coerentes. No circuito acadêmico, utilizada às vezes como um modismo, às vezes como uma palavra-chave, elaé empregada por todas as disciplinas na tentativa deenfatizar aimportância do seu objeto de estudo (WHIPP, 1996, p 261-275). Em sua análise, Whipp apóia-se no trabalho de Knights e Morgan (1991) que demonstra que estratégia não é apenas uma técnica ou um corpo de conhecimentos, mas essencialmente um discurso. Tal constatação advém de análises efetuadas com o ferramental da teoria lingüística e a partir das práticas discursivas de Foucault. A AD revela, então, que "a própria língua, símbolos e trocas em torno do tema da estratégia têm importantes resultados. Estratégia é um mecanismo de poder. As pessoas nas organizações podem ser identificadas conforme sua participação no discurso da estratégia e nas práticas a ele relacionadas" (WHIPP, 1996, p. 263). A noção dominante de estratégia está alicerçada na visão racional da administração e pressupõe a possibilidade do completo conhecimento e conseqüente domínio do ambiente. D esta promessa advém a força do discurso da estratégia (WHIPP, 1996, p. 263). Com sua força, o discurso torna-se capaz de modelar comportamentos e delimitar racionalidades que visam tanto incluir quanto excluir visões de mundo, padrões de ação etc. D esta forma, o discurso serve de instrumento de dominação à medida em que aqueles que são dominados colaboram com os dominadores ao tomarem como certo, como um dado tanto o próprio discurso quanto a sua definição da situação (G ITLIN, 1989, p. 357).

O s exemplos citados não exaurem o cabedal de estudos que tem sido desenvolvido através da AD. Tampouco cobrem o espectro de possibilidades que com ela se abrem. 0 intuito é o de ilustrar a força analítica desta "tecnologia" de pesquisa e dirigir a atenção dos estudiosos das ciências sociais em geral e da administração em particular para a sua riqueza.

\section{CONCLUSÃo}

A forma como a língua é produzida e interpretada em um dado contexto é o foco daAD. Porsuaamplitude, ela pode ser trabalhada como um fim em si mesma ou como um instrumento depesquisa em umavariedade deáreas. Portanto, o seu uso não exclui a incorporação de outras metodologias. D entre outras construcõoes, aAD estudaa estrutura lingǘsticados atos de fala, as seqüências de conversações, as atividades dafala, os registros orais e literais, eamarcação da posição -stancemarking, buscando relacioná-las às normas, preferências, e expectativas culturais, sociais, e políticas em um dado tempo e espaço.

A partir da ruptura com o imobilismo do estruturalismo, a AD passou a considerar a força contextual que condiciona o discurso e a conferir a seu processo de forma- ção uma perspectiva dialética. Estes avanços foram trazidos pela pragmática e pela teoria da argumentação (BALLALAI, 1989, p. 59). A través de um processo de desconstrução sistemática, a AD constrói como produto "um novo entender dos textos produzidos numa área, quase sempre voltado para a definição política e ideológica que esses textos encobrem. Ela é um processo de desmascaramento da palavra, numa busca da verdade que se esconde atrás dela, uma denúncia do não dito" (BALLALAI, 1989, p. 56). A AD "introduziu no domínio lingüístico o tema da história, do poder, da ideologia que não só perpassam os processos discursivos como se constituem nas suas condições de produção" (PEREIRA, 1991, p. 20). Ao partir da articulação dos processos lingüísticos com os elementos extralingüísticos e ao impor ao pesquisador, como condição indispensável à descoberta da verdade na construção do seu conhecimento de mundo, a articulação entre o discurso e suas condições de produção a AD o obriga a fazer história.

Uma certa compreensão do que seja a relação entre discurso e subjetividade estará sempre presente acionando e instrumentalizando as lentes e as escutas analíticas. A AD coloca-se como uma metodologia eficaz efactível para o trabalho investigativo de desconstrução e reconstrução dos discursos querno circuito acadêmico, querno circuito das relações de produção e trabalho, tanto na esfera lingüística, quanto na esfera histórica-social e política-ideológica. Ela toma evidente o fato de que o discurso pode funcionar como umaarmadura que se presta, a um só tempo, a um papel duplo de defesae de ataque, conforme as exigências ou interesses da ocasião.

Extrapolando a concepção do discurso como armadura, pode-se pensá-lo como uma estratégia sofisticada de delimitação de espaços sociais e intelectuais, uma estratégia de poder adotada inclusive por aqueles que trabalham a sua decomposição. Um exemplo concreto desta perspectivaéa constatação expressa por escreve Jenkins (1992, p. 163) do fato de que a forma como Bourdieu escreve constitui uma estratégia para manter e aumentar a sua distinção, reputação e statusem relação aos outros. Como Jenkins afirma, para dizer o que diz, Bourdieu não precisa escrever como escreve. Usando a linguagem como instrumento simbólico de poder, Bourdieu estabelecee perpetua hierarquias, delimitazonas de saber, de inclusão e exclusão. Analogamente, vários outros cientistas ou pensadores so ciais, dentre eles o próprio Foucault, por exemplo, que tem no discurso o seu objeto de trabalho podem ser enfocados sob esta perspectiva. Como Frost e Martin (1996, p. 599) esclarecem, na luta pela hierarquização, dominação e busca de legitimação nos estudos da administração, o silêncio, a marginalização, e a subestimação tácita são algumas das principais estratégias comumente empregadas. Estas estratégias mascaram divergências e forçam o leitor a prestar atenção aos silêncios ea ler entre as linhas daquilo queé publicado no esforço de decifrar o que está realmente sendo dito, quais questões críticas causam as exclusões ou impedem as interseções. 
Como dito por D audi (1986, p. VII) ao relatar trechos de diálogos seus com Foucault, o importante na pesquisa éa curiosidade, não aquela que busca assimilar o conhecimento convencional, mas sim a que faz o pesquisador adotar uma postura de desconstrução e explorar novos modos de pensar e ver o mundo. D esconstruir, desmistificar discursos pode ser, entretanto, apenas uma forma de reprodução de novos discursos. Talvez, como filosofa D audi (1986, p. 20), o pesquisador esteja fadado a construir discursos sobre discursos.

\section{REFERÊNCIAS BIBLIOGÁFICAS}

ALVENSO N, M.; DEETZ, S. 'Critical theory and postmodernism approaches to organizational studies', in S. CLEGG ; C. HARDY; W. NORD (eds), Handbook of organization studies. London: Sage, 1996. pp. 191-217.

BALLALAI, R. 'Notas e subsídios para a análise do discurso: uma contribuição à leitura do discurso da administração', Fórum Educacional, 13(1-2), p. 56-80, 1989.

BOURDIEU, P. 'Esboço de uma teoria prática', in R. ORTIZ (org.), Pierre Bourdieu: sociologia. São Paulo: Ática, 1983. pp. 46-81.

BRYMAN, A. Research methods and organization studies. 2. ed. London: Routledge, 1992.

CARVALHO, C. Para compreender Saussure. 4. ed. Rio de Janeiro: Editora Rio, 1984.

D AUDI, P. (1986) Power in the organisation: the discourse of power in managerial praxis. Oxford: Basil Blackwell, 1986.

FEYNMAN, R. 'Los Alamos from below', Engineering and science, 39, p. 28-43, 1976.

FOUCAULT, M. Les Mots et les Choses. Paris: Gallimard, 1966. . L'Archéologie du Savoir. Paris: Gallimard, 1969.

GADET, F. 'L'analyse de discourse et l' "interprétation"', DRLVA, 27, p. 107-133, 1982.

GITLIN, T. 'Postmodernism: roots and politics', in I. ANG US; S. JHALLY (eds), Cultural politicsin contemporary America. New York: Routledge, 1989. pp. 347-60.

HARDY, C.; CLEGG , S. 'Some dare call it power' in S. CLEGG, C. HARDY and W. NORD (eds), Handbook of organization studies. London: Sage. pp. 622-41, 1996.

HJEMSLEV, L. Le Olangage. Paris: Minuit, 1966.

HOFSTEDE, G. Culture's consequences: international differences in work-related values. London: Sage, 1980.

JENKINS, R. Pierre Bourdieu. London: Routledge, 1992.

KNIGHTS, D .; MORGAN, G. 'Strategic discourse and subjectivity: towards a critical analysis of corporate strategy in organizations', Organization Studies, 12(2), p. 251-73, 1991.

LINSTEAD, S. 'D econstruction in the study of organizations', in J. Hassard; M. Parker (eds), Postmodernism and organizations. 2. ed. London: Sage, 1994. pp. 49-70.
MAINGUENEAU, D. Novastendências em análise do discurso. 3. ed. Campinas, São Paulo: Pontes, 1997.

MARTIN, J.; FROST, P. 'The organizational culture war games: a struggle for intellectual dominance' in S. Clegg, C. Hardy; W. Nord (eds), Handbook of organization studies. London: Sage, 1996. pp. 599-621.

MEYER, M. Logique, langage, et argumentation. Paris: Hachette, 1982.

MO LINAS, A. 'A modernidade, a análise do discurso ea dispersão do sujeito', Letras de Hoje, 84(1), p. 20-60, 1991.

PÊCHEUX, M. 'Sur les contextes épistémologiques de l'analyse de discours', in Mots, Presses de la Fondation nationale des sciences politiques, 9, p. 7, 1984.

PEREIRA, A. 'Uma introdução à análise do discurso', Letras de Hoje, 84(1), p. 07-20, 1991.

REED, M. 'O rganizational theorizing: a historically contested terrain' in S. Clegg, C. Hardy and W. Nord (eds), Handbook of organization studies. London: Sage, 1996. pp. 31-56.

SAUSSURE, F. Cours delinguistique générale. Paris: Payot, 1968 $\overline{1} \overline{9} \overline{8} \overline{7}$. . Curso de lingüística geral. 13. ed. São Paulo: Cultrix,

WHIPP, R. 'Creative deconstruction: strategy and organizations' in S. Clegg, C. Hardy and W. Nord (eds), Handbook of organization studies. London: Sage, 1996. pp. 261-75. 